\title{
Investigation of Tritrichomonas foetus in cryopreserved bovine semen by culture and polymerase chain reaction
}

\author{
[Pesquisa por Tritrichomonas foetus em sêmen bovino criopreservado mediante \\ isolamento e reação em cadeia da polimerase] \\ L. Ribeiro ${ }^{1}(\mathbb{D})$ O.R. Silva ${ }^{1}$ (D) F.C. Duarte ${ }^{2}$ (D) , V.L.T. Jesus ${ }^{1}$ \\ ${ }^{1}$ Universidade Federal Rural do Rio de Janeiro, Instituto de Zootecnia, Seropédica, RJ, Brasil \\ ${ }^{2}$ Instituto Biológico de São Paulo, São Paulo, SP, Brasil
}

\begin{abstract}
Bovine Trichomoniasis (BT) is an infectious disease caused by Tritrichomonas foetus that can be transmitted either sexually or by fomites. In males, the disease is asymptomatic and permanent. T. foetus has been detected in semen samples where it is able to remain viable even when frozen. The objective of this study was to investigate the presence of $\mathrm{T}$. foetus in 27 samples of commercial frozen bovine semen by culture and Polymerase Chain Reaction (PCR). Samples were thawed in water at $37^{\circ} \mathrm{C}$. Part of the samples was inoculated in a test tube containing Diamond's medium and incubated at $35^{\circ} \mathrm{C}$. Growth was evaluated every 24 hours via direct examination under a microscope. The other part was placed in an Eppendorf tube and frozen for later molecular analysis. After 10 days of culture, all samples were negative for T. foetus. The Quick-DNA Miniprep Kit (Zymo Research) without proteinase K was used for DNA extraction. The primers used in PCR were TRF3 and TRF4. PCR results were negative for all samples. In conclusion, bovine semen samples were negative for $T$. foetus in both diagnostic methods, according to the adopted methodology.
\end{abstract}

Keywords: trichomoniasis, bovine trichomoniasis, reproductive diseases

\section{RESUMO}

A tricomonose genital bovina (TGB), uma doença infectocontagiosa causada pelo Tritrichomonas foetus, é transmitida por via venérea e fômites contaminados. Em machos a doença é assintomática e permanente. $O$ agente já foi encontrado em amostras de sêmen e é capaz de permanecer viável quando congelado. Este trabalho teve por objetivo investigar a presença de T. foetus em 27 amostras de sêmen bovino comercial congelado, por meio de cultivo e reação em cadeia da polimerase (PCR). As amostras foram descongeladas em água a $37^{\circ} \mathrm{C}$; parte foi inoculada em tubo de ensaio contendo meio Diamond, incubada a $35^{\circ} \mathrm{C}$ com consequente avaliação de crescimento e avaliada a cada 24 horas, via exame direto em microscópio, e a outra parte foi diluída em PBS para análise molecular. Após 10 dias de cultivo, todas as amostras foram negativas. Para a deteç̧ão molecular foi utilizado o kit Quick-DNA Miniprep (Zymo Research) sem proteinase K para extração do DNA. Os iniciadores utilizados na PCR foram TRF3 e TRF4. O resultado da PCR foi negativo para todas as amostras. Conclui-se que as amostras utilizadas foram realmente negativas para a presença do patógeno em ambos os métodos diagnósticos, o que comprovou a inocuidade do sêmen testado.

Palavras-chave: tricomoníase, tricomonose bovina, doenças reprodutivas

\section{INTRODUCTION}

Bovine Trichomoniasis (BT) is a venereally transmitted disease caused by a flagellated protozoan, Tritrichomonas foetus. This cosmopolitan disease generates great economic impact, as it can cause early abortion and infertility in cows. Bulls show no clinical signs and are therefore asymptomatic carriers and the main spreaders of BT in herds around the world. Diagnosis is based on the reproductive history of the farm and clinical signs observed in cows and

Corresponding author: lauraribro@yahoo.com.br

Submitted: March 17, 2021. Accepted: July 14, 2021. 
confirmed by isolation and identification of $T$. foetus by culture. Due to difficulties in isolating $T$. foetus, more sensitive and specific tests such as immunohistochemistry and Polymerase Chain Reaction (PCR) have been preferred, although their cost in Brazil is still relatively high. Despite this, the standard method is still microbiological culture, which, by itself, does not present satisfactory results. Since culture analysis depends on the observer's expertise in detecting the agent in the sample, false-negative results can appear.

BT is more frequent in extensively managed cattle, in which natural breeding (NB) is the main breeding strategy; thus, Artificial Insemination (AI) is an important prevention strategy. However, BT is also transmitted using contaminated artificial vaginas or semen from positive bulls.

Therefore, controlling trichomoniasis in Brazil is still considered a difficult task, since extensive cattle farming and natural breeding are prevalent. The cattle breeders' lack of knowledge about BT, the permanence of bulls older than 4 years in herds, and the disregard toward the preservation of bovine semen are factors that also contribute to the persistence and dissemination of BT among Brazilian herds.

Another relevant factor is T. foetus' ability to survive freezing and remain potentially infectious in bull semen. Both semen and $T$. foetus are preserved in liquid nitrogen using a similar method, and often the same cryoprotectants. Therefore, poor diagnosis can turn AI into a risk factor for BT, especially when carried out with poorly handled semen - for example, with samples frozen in the field and shared between neighboring farms, without prior laboratory analysis.

Although some studies have demonstrated the efficacy of PCR in detecting pathogens in semen and its superior performance in relation to culture (Cardoso et al., 2006; Cobo et al., 2007; Nardi Junior et al., 2014), studies focusing on $T$. foetus detection in bovine semen are still scarce. As of the date of submission of this paper, the authors are unaware of other similar research accepted for publication.
The last studies on the prevalence of $T$. foetus in the state of Rio de Janeiro were published in 2004 by Jesus et al., who observed $1.6 \%$ positive animals, and in 2009 by Rocha et al., who did not obtain positive results for BT. No more data has been published on BT in Rio de Janeiro since.

Thus, this disease invites further exploration due to the economic and health impact it causes. Adding PCR to the list of reliable diagnostic techniques for BT is necessary to increase the number of tools to fight against T. foetus in Brazil.

The objective of this study was to evaluate samples of cryopreserved bovine semen straws in order to detect Tritrichomonas foetus by culture and PCR, comparing the results obtained by the two methods.

\section{MATERIAL AND METHODS}

27 commercial frozen bovine semen straws from Artificial Insemination Centers in Southeastern Brazil were kindly provided for this study. Since they were obtained through donation, no specific criteria were used to choose the samples.

Although this study did not use animals directly, it was submitted to the Ethics Committee on Animal Use of the Institute of Animal Science at UFRRJ under protocol number 0081-10-2019.

The samples were thawed in water at $37^{\circ} \mathrm{C}$ for 30 seconds. $50 \mu \mathrm{l}$ of the samples were pipetted into Eppendorf tubes and frozen at $-20^{\circ} \mathrm{C}$ for later extraction and PCR, while the rest was inoculated into properly labeled tubes containing $2 \mathrm{ml}$ of Hank's medium and incubated at $35^{\circ} \mathrm{C}$ in an incubator.

Growth in culture was evaluated every 24 hours by direct examination of a drop of medium on a slide. Growth was observed by light microscopy (Primo Star Zeiss ${ }^{\circledR}$ ), 10x.

Cultures were transferred to a new medium every 72 hours and were considered negative after 10 days of incubation without protozoan growth. No tubes containing inoculated medium were discarded until the end of this period.

Semen was used for DNA extraction. The QuickDNA miniprep kit was used according to the manufacturer's protocol for whole blood, serum, and plasma (Zymo Research®). 
Aliquots of $50 \mu \mathrm{l}$ were thawed at room temperature and moved to $1.5 \mathrm{~mL}$ microcentrifuge tubes that received $200 \mu 1$ of lysis buffer (Genomic Lysis Buffer). The tubes were vortexed for 5 seconds and left on the bench at room temperature for 7 minutes.

After this period, the entire contents of the tubes were pipetted into a new tube, containing a column with a filter to retain DNA. The tubes were centrifuged at $10,000 \mathrm{xg}$ for 1 minute and discarded; the filter column was moved to a new tube to which $200 \mu$ l of DNA Pre-Wash Buffer were added. The tubes were centrifuged again as in the previous step.

After centrifugation, 500 $\mu 1$ of g-DNA Wash Buffer were added to all tubes, which were then centrifuged at $10,000 \mathrm{xg}$ for 1 minute. Finally, the column was transferred to a new microcentrifuge tube to which $70 \mu \mathrm{l}$ of Elution Buffer were added. Samples were incubated for 5 minutes at room temperature and then centrifuged for 30 seconds to elute the extracted DNA.

After this process, columns were discarded, and the material obtained after elution was frozen at $20^{\circ} \mathrm{C}$ in a new tube for further molecular analysis.

A set of primers which amplified the 5.8S rRNA sequence and the ITS1 and ITS2 regions was used for $T$. foetus detection, as described by Felleisen et al. (1998). The ITS1 and ITS2 regions are molecular markers specific for T. foetus (Felleisen, 1997; Felleisen et al., 1998). The primers were TRF-3 (5'CGGGTCTTCCTATATGAGACAGAACC-3') and TRF-4 (5'-CCTGCCGTTGGATCAGTTTCGTTAA3') (Felleisen et al., 1998).

For each PCR reaction, the following were used: $8 \mu \mathrm{l}$ of $\mathrm{H} 2 \mathrm{O}, 12.5 \mu \mathrm{l}$ of Taq 2x Master mix RED $1.5 \mathrm{mM} \mathrm{MgCl} 3$ (Ampliqon $\AA$ ), $2.5 \mu \mathrm{l}$ of the sample, and $1 \mu 1$ of each primer.

T. foetus' DNA isolated from the genital tract of a positive bull, from the Laboratory of Animal Parasitology of the Biological Institute of São
Paulo's collection, was used as a positive control. An aliquot of equal volume of the reaction mixture, without the application of a semen sample or standard strain, was used as a negative control.

The reaction was conducted in a thermal cycler (Axygen ${ }^{\circledR}$ MaxyGene Thermal Cycler II, USA) using the following programming: denaturation at $94^{\circ} \mathrm{C}$ for 30 seconds, annealing at $67^{\circ} \mathrm{C}$ for 30 seconds, and extension at $72^{\circ} \mathrm{C}$ for 90 seconds. Forty cycles were performed with a final extension step of 15 minutes at $72^{\circ} \mathrm{C}$.

Aliquots from this reaction were analyzed by electrophoresis on a 1.5\% agar gel, stained with ethidium bromide (dissolved in 0.5X Tris-BorateEDTA solution) for visualization in a documentation system (Axygen ${ }^{\circledR} \quad \mathrm{Gel}$ Documentation System BL, USA). A $1 \mathrm{~kb}$ molecular marker was used as reference. The expected fragment size was $347 \mathrm{bp}$.

\section{RESULTS AND DISCUSSION}

All samples analyzed by culture were negative for parabasalids. Tubes were kept for 10 days in the incubator for analysis and $T$. foetus was not detected in any of them. A similar result was observed by Parsonson et al. (1974), who also did not obtain culture positive for $T$. foetus from semen, even though positive samples from the preputial washing of bulls were used.

Samples used in PCR also presented a negative result, as shown in Figure 1.

Figure 1 shows that all clinical samples were negative for $T$. foetus. Only the positive control had a positive reaction, as expected. The reaction was probably free of contaminants, since the negative control was not amplified.

The results from both techniques demonstrate the absence of the parasite in the samples studied, which was expected. Since the two techniques obtained negative results, it was not possible to compare them. 


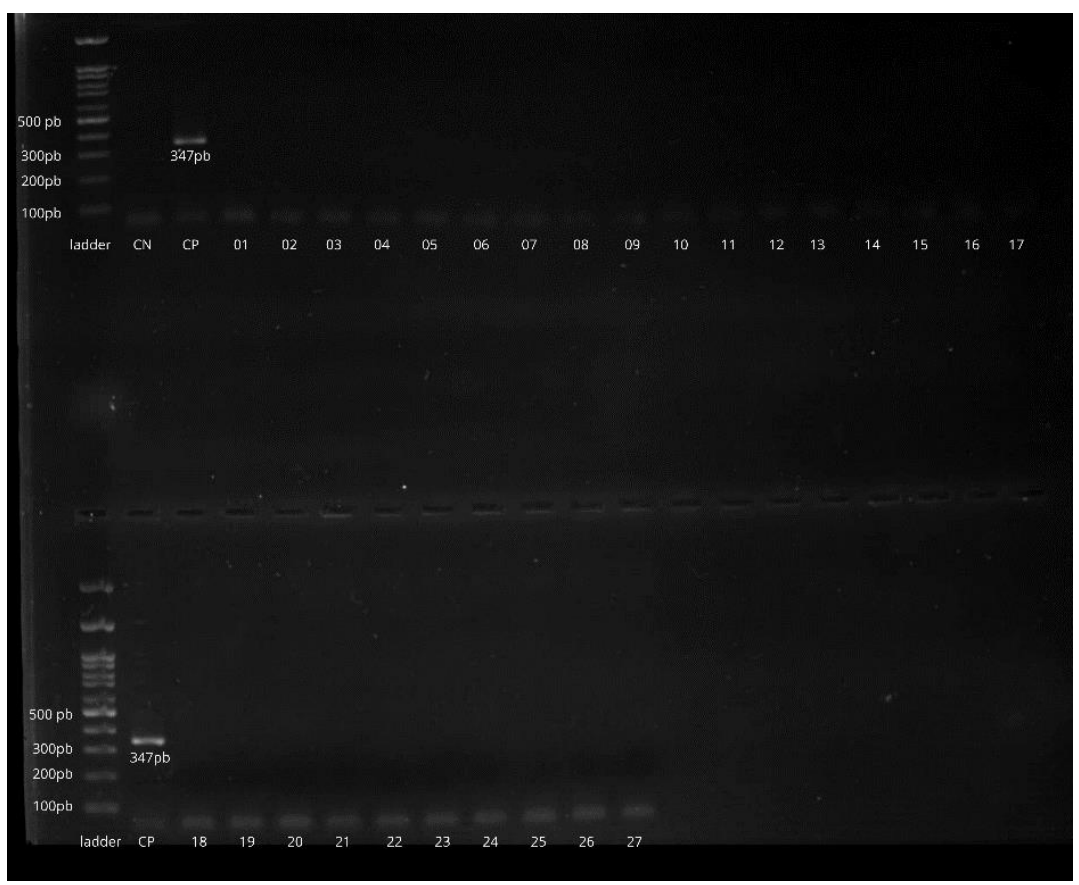

Figure 1. 1.5\% agarose gel electrophoresis of T. foetus' PCR products. CN - negative control, $\mathrm{CP}$ - positive control, ladder - $1 \mathrm{~kb}$ DNA molecular marker.

The negative result was expected because we employed commercial samples, which had been previously processed and were obtained from animals that had undergone consecutive testing for T. foetus. On the other hand, it is not possible to state whether the experiment would have the same result if performed with fresh, unprocessed semen.

Tritrichomonas foetus is an important pathogen and remains present in Brazilian cattle herds. Despite the decrease in prevalence, bovine trichomoniasis is not yet eradicated and efforts to improve diagnostic methods and epidemiological surveillance must be made (Oliveira et al., 2015; Oliveira et al., 2016).

Studies have reported data on the presence of several pathogens in bovine semen, such as Brucella abortus (Nardi Junior et al., 2014), Mycoplasma bovis (Haapala et al., 2018), Ureaplasma diversum (Marques et al., 2009), Histophilus somnus (Dias et al., 2014), and Neospora caninum (Doosti et al., 2015).

Although the present study did not demonstrate a venereal transmission of trichomoniasis by PCR, monitoring bovine semen is still of great importance, since it is widely used in Brazilian cattle farms, serving as a source of infection for cows (Givens; Marley, 2008; Givens, 2018).

With the advancement of diagnostic methods, both in human and veterinary medicine, PCR has been established as a fast, specific, and sensitive technique that can be a complementary tool in pathogen detection (Felleisen et al., 1998; Rae; Crews, 2006; Givens; Marley, 2008; Marques et al., 2009).

PCR has been used on a wide variety of samples, including semen. However, the extraction of etiological agents' DNA from semen is not trivial, because it contains several inhibitors that interfere with amplification and generate false results.

The host's genetic material, which contains large amounts of DNA, is one of the main PCR inhibitors. Separating the host's genetic material from the rest of the semen can be a way to avoid inhibition. One could achieve this, for example, by maintaining the integrity of sperm heads or by removing them from the solution, depending on the agent under investigation. Semen fractions were not separated in this study, which may have impacted results. 
However, Takiuchi et al. (2003) compared extraction methods, without the separation of semen fractions, and obtained satisfactory results.

The phenol-chloroform method, with or without proteinase $\mathrm{K}$ digestion, is widely used for DNA extraction from semen, being effective for several etiological agents, including bacteria (Takiuchi et al., 2003; Cardoso et al., 2006; Magajevski and Girio, 2008). However, electrophoresis may also have determined the result in these studies.

The present study used a commercial kit for DNA extraction as it is an effective, practical, fast, and safe method, despite its high cost (Yao et al., 2011; Oliveira et al., 2016; Dąbrowska et al., 2020; Silveira et al., 2020).

As highlighted by Magajevski and Girio (2008), the standardization and correct choice of the extraction technique is fundamental to obtain consistent results, especially with dense, viscous materials that may contain inhibitors, such as semen. Because of this and other logistical and safety reasons, we used an extraction kit in this study. We suggest, however, that new studies on the same topic test other protocols.

Detecting the presence of other parabasalids in the analyzed samples was not possible, since the primers used were specific for $T$. foetus. Other trichomonads have already been identified in semen of breeding bulls (Asadpour; Salehi; Jafari, 2011). However, since we used fresh semen samples, it is not possible to claim that we would obtain the same result.

The samples for the present study were chosen because they had not yet been surveyed for $T$. foetus. In addition, other studies have shown that PCR can have better results when performed directly with pure samples rather than with culture samples (Ginter Summarell et al., 2018). Since it was not possible to use the parabasalid in vivo, we employed a previously extracted DNA sample as positive control.

Although more recent studies have used other types of PCR to detect the agent, we employed conventional PCR in this study due to logistics. A North American study showed that quantitative real-time PCR (RT-qPCR) presented 100\% sensitivity and specificity for smegma samples. In comparison, PCR analysis of culture aliquots showed 5\% less sensitivity (Ginter Summarell et al., 2018). Therefore, new techniques and methodologies may obtain a different result than the one obtained in the present study.

Testing different methodologies and performing smaller experiments to standardize the technique is necessary to identify the most sensitive method.

\section{CONCLUSION}

The presence of Tritrichomonas foetus was not detected in the samples used, considering the techniques and methodologies employed. However, to confirm the result obtained by DNA extraction and PCR, more data and experiments are needed, including the use of a semen sample contaminated with live $T$. foetus as a positive control. Finally, we conclude that research using molecular biology techniques is necessary, since many studies prove the superior performance of PCR when compared to classical methods.

\section{ACKNOWLEDGEMENTS}

The present study was carried out with the support of the Coordenação de Aperfeiçoamento de Pessoal de Nível Superior - Brazil (CAPES) Financing Code 001.

\section{REFERENCES}

ASADPOUR, R.; SALEHI, N.; JAFARI, R. PCR detection of trichomonad species in the semen of bulls. Bul. J. Vet. Med., v.14, p.215-220, 2011.

CARDOSO, M.V; TEIXEIRA, S.R.; MIYASHIRO, S. et al. Estudo comparativo entre técnicas de isolamento o PCR para detecção de Mycoplasma e Ureaplasma diversum em muco prepucial e sêmen in natura de touros de monta natural e central de inseminação artificial. Arq. Inst. Biol., v.73, p.33-40, 2006.

COBO, E.R.; FAVETTO, P.H.; LANE, V.M. et al. Sensitivity and specificity of culture and PCR of smegma samples of bulls experimentally infected with Tritrichomonas foetus. Theriogenology, v.68, p.853-860, 2007.

DĄBROWSKA, J.; KARAMON, J.; KOCHANOWSKI, M. et al. Tritrichomonas Foetus: a study of prevalence in animal hosts in Poland. Pathogens, v.9, p.203, 2020. 
DIAS, F.E.F.; NUNES, C.M.; CAVALCANTE, T.V. et al. Detecção de Histophilus somni (Haemophilus somnus) no sêmen bovino mediante reação em cadeia pela polimerase (PCR). Rev. Acad. Cienc. Anim., v.12, p.11, 2014.

DOOSTI, A.; KHAMESIPOUR, F.; NEKOEI, S.; LUTVIKADIC, I. Survey for the presence of Neospora caninum in frozen bull's semen samples by PCR assay. Asian Pac. J. Trop. Dis., v.5, p.7-12, 2015.

FELLEISEN, R.S.J. Comparative sequence analysis of $5.8 \mathrm{~S}$ rRNA genes and internal transcribed spacer (ITS) regions of trichomonadid protozoa. Parasitology, v.115, p.111-119, 1997.

FELLEISEN, R.S.J.; LAMBELET, N.; BACHMANN, P. et al. Detection of Tritrichomonas foetus by PCR and DNA enzyme immunoassay based on rRNA gene unit sequences. J. Clin. Microbiol., v.36, p.513-519, 1998.

GINTER SUMMARELL, C.C.; HAIRGROVE, T.B.; SCHROEDER, M.E. et al. Improvements in Tritrichomonas foetus molecular testing. J. Vet. Diagn. Invest., v.30, p.603-608, 2018.

GIVENS, M.D. Review: Risks of disease transmission through semen in cattle. Animal, v.2, p.s165-s171, 2018.

GIVENS, M.D.; MARLEY, M.S.D. Pathogens that cause infertility of bulls or transmission via semen. Theriogenology, v.70, p.504-507, 2008.

HAAPALA, V.; POHJANVIRTA, T.; VÄHÄNIKKILÄ, N. et al. Semen as a source of Mycoplasma bovis mastitis in dairy herds. Vet. Microbiol., v.216, p.60-66, 2018.

JESUS, V.L.T.; PEREIRA, M.J.S.; ALVES, P.A.M.; FONSECA, A.H. Fatores intrínsecos do hospedeiro associados à prevalência de tricomonose genital bovina. Rev. Bras. Parasitol. Vet., v.13, p.159-163, 2004.

MAGAJEVSKI, F.S.; GÍRIO, R.J.S. Avaliação da sensibilidade da PCR frente a quatro técnicas para extração de DNA de Leptospira interrogans sorovar pomona em sêmen bovino experimentalmente contaminado. Ars Vet., v.24, p.29-33, 2008.
MARQUES, L.M.; BUZINHANI, M.; NETO, R.L. et al. Detection of Ureaplasma diversum in bovine semen straws for artificial insemination. Vet. Rec., v.165, p.572-573, 2009.

NARDI JUNIOR, G.; RIBEIRO, M.G.; MEGID, J. et al. Relação entre exame andrológico, sorologia, cultivo microbiológico e PCR do sêmen na brucelose bovina e sua importância ao agronegócio. In: JORNADA CIENTÍFICA E TECNOLÓGICA DA FATEC, 3., 2014, Botucatu. Anais... Botucatu: [s.n.], 2014.

OLIVEIRA, J.M.B.; BATISTA FILHO, A.F.B.; BORGES, J.M. et al. Tritrichomonas foetus in bulls in the State of Pernambuco, Brazil. Rev. Bras. Med. Vet., v.38, p.449-453, 2016.

OLIVEIRA, J.M.B.; SILVA, G.M.; BATISTA FILHO, A.F.B. et al. Prevalence and risk factors associated with bovine genital campylobacteriosis and bovine trichomonosis in the state of Pernambuco, Brazil. Trop. Anim. Health Prod., v.47, p.549-555, 2015.

PARSONSON, I.M.; CLARK, B.L.; DUFTY, J.H. The Pathogenesis of Tritrichomonas foetus Infection in the Bull. Aust. Vet. J., v.50, p.421423, 1974.

RAE, D.O.; CREWS, J.E. Tritrichomonas foetus. Vet. Clin. N. Am. Food Anim. Pract., v.22, p.595611, 2006.

ROCHA, F.S.; JESUS, V.L.T.; TORRES, H.M. et al. Investigação de Campylobacter fetus e Tritrichomonas foetus na mucosa prepucial de touros da região do Médio Paraíba, RJ. Ciênc. Rural, v.39, p.1587-1590, 2009.

SILVEIRA, C.S.; FRAGA, M.; MONESIGLIO, C. et al. Detección de Tritrichomonas foetus por PCR en esmegma prepucial de toros en Uruguay. Veterinaria, v.56, p.27-34, 2020.

TAKIUCHI, E.; MÉDICI, K.C.; ALFIERI, A.F.; ALFIERI, A.A. Otimização da reação em cadeia pela polimerase (Semi Nested-PCR) para a detecção do herpesvírus bovino tipo $1 \mathrm{em}$ fragmentos de órgãos fetais e em sêmen de bovinos naturalmente infectados. Semin. Ciênc. Agrar., v.24, p.43, 2003.

YAO, C.; BARDSLEY, K.D.; LITZMAN, E.A. et al. Tritrichomonas foetus infection in beef bull populations in Wyoming. J. Bacteriol. Parasitol., v.2, p.117, 2011. 